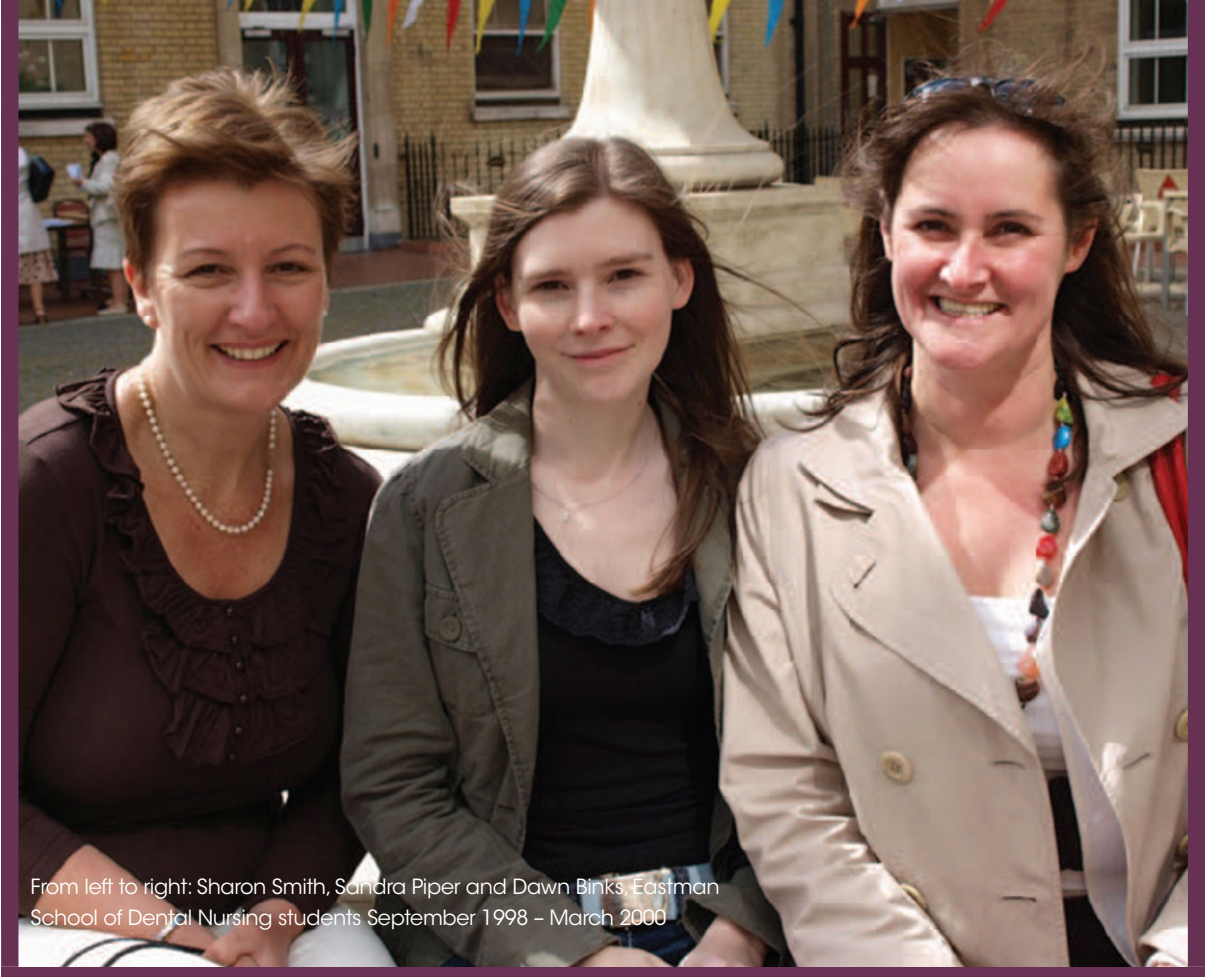

\section{EASTMAN SCHOOL OF NURSING CELEBRATES 6OTH ANNIVERSARY}

On the afternoon of 14 May 2011, 70 dental nurse students, past and present, came together to celebrate the 60th anniversary of the Education and Training Assessment Centre for Dental Nurses, formerly the Eastman School of Nursing.

The dental nurses were joined by representatives of global oral health charity Dentaid and the Cleft Lip and Palate Association in the courtyard of UCLHT Eastman Dental Hospital to pay tribute to a longstanding and influential school that has played a vital role in the oral health care of the nation.

Activities included tours of the Eastman building, which brought back fond memories to many, as well as afternoon tea in the courtyard where friends old and new could relax and reminisce. A caricaturist was also on hand to add light-hearted entertainment to the proceedings.

Nostalgia was evoked by the screening of a black and white spoof video of life at the Eastman in the 1960s, together with a large collection of past student photographs, former examination papers and the Eastman Shield and Cup for students who have gained distinction.

\section{NEWS IN BRIEF}

Confident Dental Care in Stroud won the Preventative Practice of the Year Award 2010. The dental team, headed up by Ewa Rozwadowska and Colin Neil, created the Steps to Health programme which helps patients take control of their dental health.

The British Society of Dental Hygienists and Therapists' (BSDHT's) Oral Health Conference will be returning to Bournemouth on 18-19 November 2011. A packed programme of eminent speakers, sessions and workshops along with excellent networking opportunities, a conference dinner and Friday night party are all on offer. More information and a full programme are available at www.bsdht.org.uk.

Alina Baldovinescu, a dental nurse and manager from Central Dental Care in Wembley, London, was awarded the title of ILM Learner of the Year 2011 at a glittering ceremony in London. Alina recently completed her ILM Level 5 Diploma in Management with UMD Professional.

City \& Guilds were pleased to award 14 Licentiateships to the City \& Guilds of London Institute (LCGI) in Dental Nursing. Recipients included Hayley Stout and Claire Hoskin. The City \& Guilds Graduation Ceremony for 2011 was held at the Merchant Taylors' Hall in the heart of the City of London.

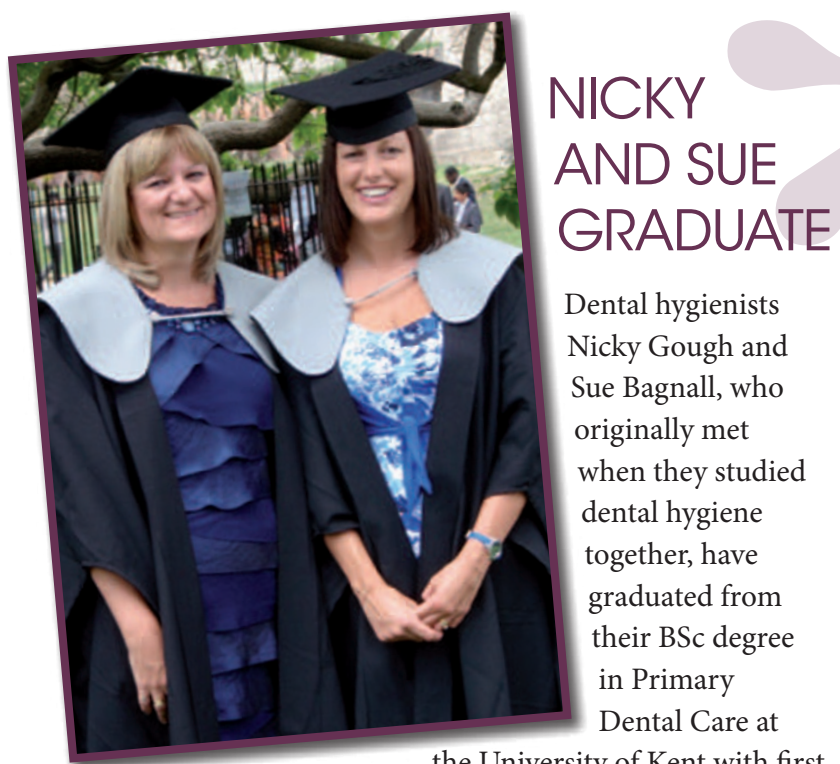

the University of Kent with first

class and upper second class honours respectively.

Nicky and Sue featured in the Vital cover story 'I am beginning to find my professional voice' in autumn 2009 and were part of the first cohort of students on the BSc degree course. They also run cpd4dentalnurses.co.uk.

\title{
JILL TAKES THE HELM OF THE BDPMA
}

\section{The British Dental Practice}

Managers' Association (BDPMA)

has welcomed a new president, Jill Taylor, to the helm.

Jill, a 34-year-old practice manager from Kilwinning, Ayrshire, Scotland was voted in by members at the BDPMA's AGM at the British Dental Conference and Exhibition in Manchester on Saturday May 21.

Jill, practice manager at Botanics Dental Care in Glasgow, said she is delighted with her prestigious role within the BDPMA, which

provides support, expert advice and information to practice managers and administrators.

It is an honour to become president of the BDPMA and I am very much looking forward to my two

\section{years in} office, said Jill. 'There are some exciting changes taking place

within the organisation, which will be revealed in more detail at the BDTA Dental Showcase in October.'

Jill started her career as a dental nurse in 1994 and joined the BDPMA in late 2008, where she became a regional co-ordinator within a year. Hannah Hume, a practice manager in London, is the new vice president.

The BDPMA was formed in 1993 and now has more than 800 members. 